\title{
RELIGION AND RITUAL IN THE WESTERN PROVINCES
}

\author{
By LOUISE REVELL
}

\section{Introduction}

The search for a more powerful entity to provide some form of order to the chaotic nature of human existence is a phenomenon that can be seen throughout much of human history. For a Roman, the gods were everywhere, as powerful forces with an interest in all aspects of daily life. Religion formed part of the broad-based homogeneity of the western provinces following the process of cultural transformation after conquest. Inscriptions, sculpture, and temple architecture all point to a similar material culture, and, although there is an apparent continuity in the names of the deities being worshipped from the pre-Roman to the Roman periods, their association with the traditional gods of Rome through syncretism negates the idea of direct continuity. However, religious changes are often overlooked in accounts of the Romanization of the western provinces, and we are left with the rather uncritical concept of 'Romano-Celtic' religion as a hybrid phenomenon. ${ }^{1}$ There is a danger of using the archaeological evidence of temples and inscriptions as diagnostic of change, rather than undertaking a more rigorous analysis in order to understand how religion and ritual formed part of this broad-based homogeneity, and the way in which the people of the provinces made sense of how to act and behave within a new social and political world. Furthermore, through creating the hybrid of Romano-Celtic, there is the temptation to concentrate on the identification of the Celtic (or pre-Roman) and Roman elements, and then to think about them in isolation, downplaying the dynamic way in which the people of the provinces negotiated their way through the new imperial context.

In this paper, I propose to explore how part of these cultural changes involved learning different ways of communicating with the

${ }^{1}$ G. Woolf, 'The Religious History of the Northwest Provinces', fournal of Roman Archaeology 13 (2000), 615; M. Millett, 'Rethinking Religion in Romanization', in J. Metzler, et al. (eds.), Integration in the Early Roman West. The Role of Culture and Ideology, Dossiers d'Archéologie du Musée National d'Histoire et d'Art IV (Luxembourg, 1995), 93. 
gods: new ways of interacting with, and placating, a higher force. I want to move beyond seeing the material culture from religious sites as being representative of cultural identity, and instead think about how it was part and parcel of certain ways of acting. Through these actions, the people of these communities joined in a much wider ideology of religion and religious practice. Thus, we are able to move beyond the local scale, and explore how ritual formed one of the social structures which held together the Roman empire and which formed part of a shared Roman identity. For this reason, I have deliberately chosen case studies from two different provinces: Baetica in Southern Spain and Britain. This allows me to move beyond a local or provincial based study, and think about how a much broader-based ethnic identity was being articulated. ${ }^{2}$ Without the textual sources used to reconstruct religious practice in Rome and Italy, we are largely reliant upon the archaeological remains, here including religious dedications and iconography. In this paper, I want to use the evidence from two sites to explore the nature of these rituals, and in particular the paradox which is inherent within the material culture of the provinces: the paradox of similarity and difference.

\section{Detecting change in provincial religion}

Approaches to religion in the western provinces have concentrated on deities and temples, interpreting them through a discourse of Romanization. This has created a dichotomy between 'Roman' and 'native', or 'Roman' and 'Celtic', which has then been applied to their classification. This has led to the characterization of temple architecture, for example, as either Roman, meaning a quadrangular podium temple, or as Romano-Celtic, a round or square tower structure surrounded by a single storey porch or walkway. ${ }^{3}$ This concentration on classification as indicative of cultural change has led to an approach to temples which has been mainly descriptive, and which has focussed on the central shrine, rather than the wider complex,

\footnotetext{
2 Most extended studies of Romanization concentrate on a single province or related group of provinces; for example, on Britain: M. Millett, The Romanization of Britain. An Essay in Archaeological Interpretation (Cambridge, 1990) and D. Mattingly, An Imperial Possession. Britain in the Roman Empire, $54 B C-A D 409$ (London, 2006); on the Gallic provinces: G. Woolf, Becoming Roman. The Origins of Provincial Civilization in Gaul (Cambridge, 1998); on Greece: S. E. Alcock, Graecia Capta. The Landscapes of Roman Greece (Cambridge, 1993). For a discussion of differences in scale, A. Gardner, 'Social Identity and the Duality of Structure in Late Roman-period Britain', Fournal of Social Archaeology 2.3 (2002), 323.

3 M. J. T. Lewis, Temples in Roman Britain (Cambridge, 1966).
} 
incorporating the surrounding area and any associated buildings. The appearance of Roman-style temples is then used to identify and quantify cultural change, rather than exploring the role of such buildings in the religious ritual. There is also a search for a pre-Roman phase to religious sites, with claims for continuity of cult place at times based on somewhat flimsy archaeological evidence and assumptions about the kind of places the pre-Roman peoples would have venerated. ${ }^{4}$ The alternative form of evidence is the names of the deities, taken from inscriptions on stone and other media, and used to identify their attributes and realms of influence and then to construct distribution patterns of their worship. Again, the tendency has been to identify any individual deity as Roman or Celtic, with the eastern mystery cults of Mithras and Dolichenus, for example, forming a third strand. ${ }^{5}$ There are two problems with this. The first is the exclusion of eastern deities such as Mithras from the Roman deities, thereby assuming that in the provinces they were viewed in the same way as they were in Rome. Secondly, the phenomenon of syncretism, or double naming, cannot be included within these categories. Whereas once the pairing of indigenous deities with a Roman counterpart was seen as a stage in the cultural transformation of British communities, in reality this is less straightforward. Jane Webster, for example, has pointed to the fact that double-naming was more frequently used by military and high-status administrative ranks, whereas the indigenous population were more likely to worship the god under a single name. ${ }^{6}$ From this she has argued that the process of interpretatio romana involved the active subjugation of the Celtic deity under the Roman side of the partnership, setting up an unequal power relationship and transforming its original character.

I would suggest that there is a third approach that can be used to understand the role of religion in the process of cultural change: reconstructing ritual practice through a detailed, contextual interpretation of the material culture evidence. This approach moves away from seeing material culture as a passive reflection of cultural identity,

\footnotetext{
${ }^{4}$ See, for example, a critical discussion of the evidence for pre-Roman origins to the Altbachtal at Trier in J. Scheid, 'Les temples de l'Altbachtal à Trèves: un "sanctuaire national"?', Cahiers du Centre Glotz 6 (1995), 227. A very similar demolition can be made of the argument for Iron-Age worship at Bath.

${ }^{5}$ See, for example, E. Birley, 'The Deities of Roman Britain', in H. Temporini and W. Haase (eds.), Aufstieg und Niedergang der Romischen Welt II 18.1 (Berlin, 1986), 3.

${ }^{6}$ J. Webster, 'Interpretatio: Roman Word Power and the Celtic Gods', Britannia 26 (1995), 153; Amy Zoll has similarly challenged this paradigm: for example, Zoll, 'A View through Inscriptions. The Epigraphic Evidence for Religion at Hadrian's Wall', in Metzler, et al. (n. 1), 129.
} 
and instead sees it as playing an active role in the ways in which people make sense of the world around them. Our sense of who we are and how we fit into a society is, in part, mediated through repeated, daily routines, and, within these routines, we use material such as what we wear, what we carry, and the decoration of the space around us as a way to both project something about ourselves, and to internalize that self-image. ${ }^{7}$ The routines of religious worship operate on a number of different levels: defining boundaries between mortal and divine, and also creating shared social identities firmly located within the earthly realm. Ancient historians have seen ritual as fundamental to the relationship between Romans and the divine, ${ }^{8}$ and John Scheid goes so far as to characterize Roman religion as being centred round correct practice (orthopraxis) rather than belief in specific deities. ${ }^{9}$ Thus, the repeated performance of specific rites such as sacrifice, vows, and festivals has been seen as forming a core part in the formulation of religious authority and a shared Roman identity. ${ }^{10}$ This has run in tandem with the work of post-processual archaeologists, who have explored how ritual informed the ways through which people understood their relationship with the gods, during both prehistoric and historic periods. ${ }^{11}$ However, the study of ritual in the western provinces has largely fallen between these two camps, and has failed to make an impact on our approaches for understanding religious change. Following on from J. D. Hill's work on structured deposition in the Iron Age, there has been some analysis of ritual deposition in pits and shafts, ${ }^{12}$ but there has been little detailed

7 There are a number of theoretical approaches which use these ideas, including Bourdieu's theory of practice (P. Bourdieu, Outline of a Theory of Practice, trans. R. Nice [Cambridge, 1977]), and Butler's idea of performativity (J. Butler, Bodies that Matter. On the Discursive Limits of Sex [London, 1993]). Here, I follow Giddens' structuration theory, which draws upon the work of Goffmann: A. Giddens, The Constitution of Society. Outline of a Theory of Structuration (Oxford, 1984); E. Goffmann, The Presentation of the Self in Everyday Life (New York, NY, 1959).

8 D. Feeney, Literature and Religion at Rome. Cultures, Contexts and Beliefs (Cambridge, 1998); see also, Woolf (n. 1), esp. 617-8.

${ }_{9}$ J. Scheid, An Introduction to Roman Religion (Edinburgh, 2003), 18.

10 M. Beard et al., Religions of Rome, 2 vols., Vol. 1. A History (Cambridge, 1998), esp. 42-54; also the three papers by John North in M. Beard and J. North (eds.), Pagan Priests. Religions and Power in the Ancient World (Oxford, 1990).

${ }^{11}$ See, for example, J. C. Barrett, 'Towards an archaeology of ritual', in P. Garwood et al. (eds.), Sacred and Profane (Oxford, 1991), 1; J. C. Barrett, Fragments from Antiquity. An Archaeology of Social Life in Britain, 2900-1200 BC (Oxford, 1994); C. P. Graves, The Form and Fabric of Belief. An Archaeology of the Lay Experience of Religion in Medieval Norfolk and Devon, British Archaeological Reports 311 (2000).

${ }_{12}$ J. D. Hill, Ritual and Rubbish in the Iron Age of Wessex. A Study on the Formation of a Specific Archaeological Record, British Archaeological Reports 242 (1995); for examples of similar ideas regarding the Roman period: S. Clarke, "Abandonment, Rubbish Disposal and "Special" 
examination of the ritualized use of temple space. Accounts of provincial rituals have been sketchy, providing sweeping surveys of a 'typical' picture using material drawn from a range of sites, thus divorcing it from its detailed local context. ${ }^{13}$ Similar approaches to Medieval ritual have been criticized as producing a normative picture which is then reimposed onto the local context, ${ }^{14}$ and the same can be argued for the Roman period. This has the result of downplaying the local variability evident in the archaeological record.

Through a detailed investigation of the archaeological evidence of temple sites, we can reconstruct the rituals carried out by the people who used these sites: how they moved through these spaces, which areas they could access, what they could see, and the scale of the actions. The associated material, such as inscriptions and votive offerings, enables us to flesh this out, and give some idea of the stated motivation. These repeated actions formed the basis of how these provincial societies understood the divine: they encountered their religious truths in part through their knowledge of how to act in specific situations and through the performance of those actions. ${ }^{15}$ It is tempting to downplay this knowledge, as we lack the evidence that these communities were aware of the traditions and the reasons for these rituals, but this is to overlook distinctions between different forms of knowledge. Giddens has stressed the difference between discursive and practical knowledge: our practical knowledge lies in our ability to navigate our way through specific situations, our knowledge of the appropriate ways of acting, whilst our discursive knowledge is our ability to account for these actions, and explain our reasons for them. ${ }^{16}$ Roman writers dealing with ritual were entering into a debate which rested upon their discursive knowledge of the origins of a particular ritual, for example, but those enacting the rituals were taking part in an equally powerful dialogue about the

Deposits at Newstead', in K. Meadows, et al. (eds.), TRAC96. Proceedings of the Sixth Annual Roman Archaeology Conference, Sheffield 1996 (Oxford, 1997), 73; P. Woodward and A. Woodward, 'Dedicating a Roman Town. Urban Foundation Deposits in Roman Britain', World Archaeology 36.1 (2004), 68.

${ }^{13}$ For example, M. Green, The Gods of the Celts (Godalming, 1986); M. Henig, Religion in Roman Britain, 2nd edn. (London, 1995), 128-67.

${ }_{14}$ C. P. Graves, 'Social Space in the English Medieval Parish Church', Economy and Society 18 (1989), 297, 303.

15 T. Asad, 'Anthropological Considerations of Religions. Reflections on Geertz', Man 18 (1983), 237; Barrett, (n. 11)'; some of these ideas are applied to the Roman period in C. Smith, 'Ritual and Archaeology in Early Latium', in S. Cottam, et al. (eds.), TRAC94. Proceedings of the Fourth Annual Theoretical Roman Archaeology Conference, Durham 1994, (Oxford, 1995), 57.

16 Giddens (n. 7), xxiii. 
correct way of interacting with the gods through their commitment to that ritual as a way to influence the will of the gods.

\section{The sanctuary to Sulis Minerva}

The first case study I want to deal with is the temple to Sulis Minerva at Bath, one of the most important religious sites in Roman Britain. ${ }^{17}$ Constructed during the Flavian period, the temple formed the centre of a quasi-urban settlement of unknown status (figure 1). The temple itself seems to have been part of a wider complex, with a physical link between the sacred spring and the thermal baths and the remains of a second probable monumental complex opposite. It is unclear who was responsible for the construction of the shrine: the excavators of the temple precinct argue for official involvement, possibly at the instigation of the provincial governor, although Martin Henig has more recently put forward the case for the local client king Togidubnus as proof of his loyalty to Rome in the wake of the Boudiccan rebellion. ${ }^{18}$ The name of the town (Aquae Sulis) and the number of dedications to Sulis mean that we can be fairly certain about the temple's association with the goddess. She is paired with Minerva in two inscriptions (RIB 146 and 150) and on the inscribed paterae found in the temple spring, ${ }^{19}$ suggesting her appropriation and accommodation within the Roman pantheon.

The layout of the town is difficult to reconstruct, but the central position of the temple and the baths suggests that these were the focal structures. The podium temple was surrounded by a precinct incorporating the natural thermal spring (figure 2), which fed the adjoining baths complex comprising a large thermal bath (the Great Bath) and two suites of heated rooms. ${ }^{20}$ The temple precinct was increasingly monumentalized with porticoes, and the spring was enclosed within a dedicated building in the third century. Opposite the entrance are

17 The most important excavations on the temple site took place in 1979 and 1980, and are published in B. W. Cunliffe and P. Davenport, The Temple of Sulis Minerva at Bath. Volume 1: The Site, Oxford Committee for Archaeology Monograph 7 (1985); B. W. Cunliffe (ed.), The Temple of Sulis Minerva at Bath. Volume 2: The Finds from the Sacred Spring, University of Oxford Archaeological Monograph 16 (1988). There is some uncertainty over the name of the goddess: although usually 'Sulis', in fact it could equally be 'Sul'.

18 Cunliffe and Davenport (n. 17); M. Henig, 'A New Shining Star over Bath', Oxford fournal of Archaeology 18.4 (1999), 419.

${ }_{19}$ R. S. O. Tomlin, 'Inscriptions on Metal Vessels', in Cunliffe (n. 17), 55.

20 B. W. Cunliffe, Roman Bath, Reports of the Research Committee of the Society of Antiquaries of London 24 (London, 1969), 95-131. 


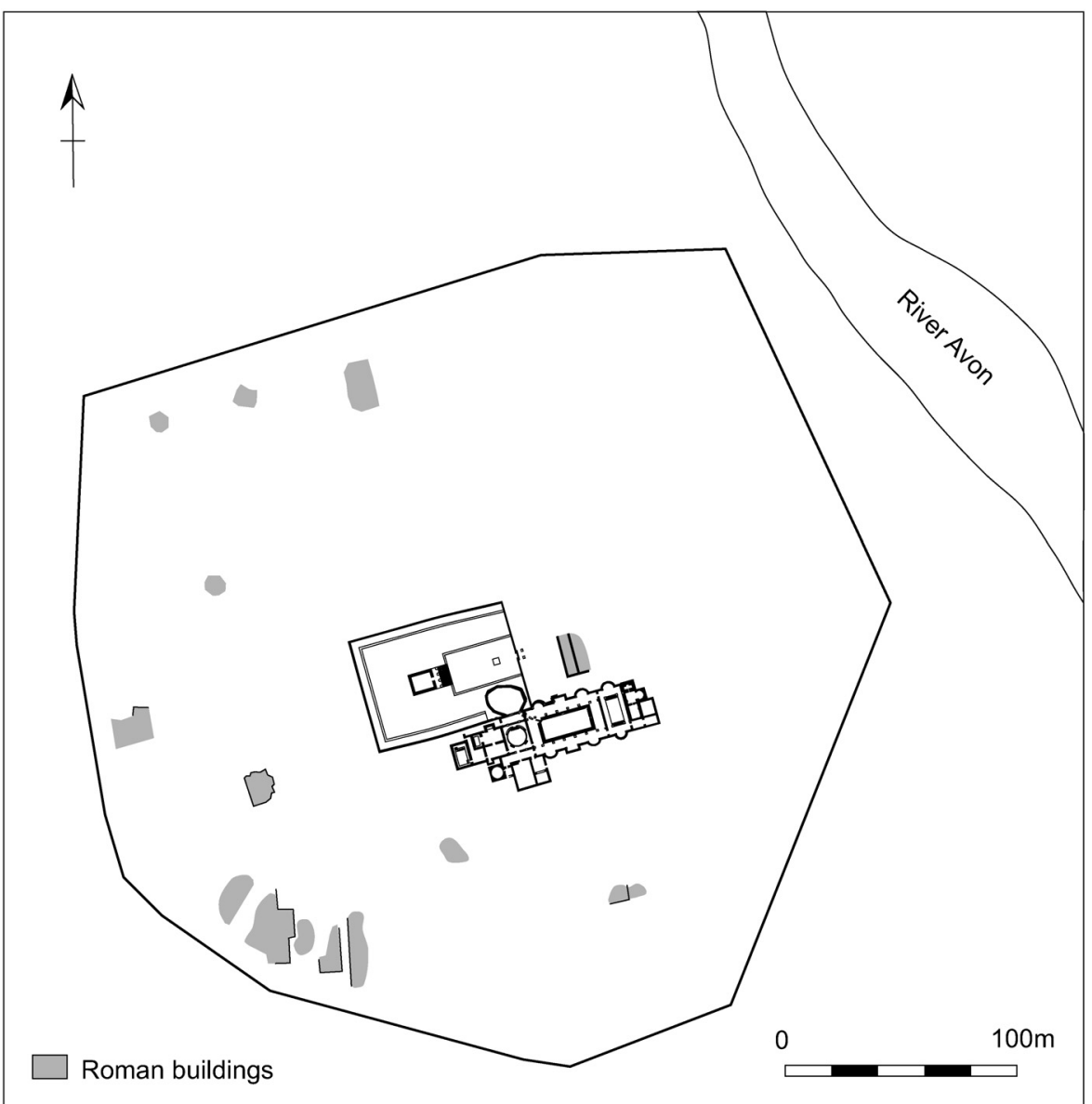

Figure 1. The Roman remains at Bath. After Cunliffe and Davenport (n. 17), figure 7; redrawn by Penny Copeland.

traces of monumental walls suggesting a second precinct, and the masonry remains of an elaborate circular structure have led Cunliffe to argue that this precinct was occupied by a tholos. ${ }^{21}$ Remains of two other baths associated with thermal springs have also been uncovered, although neither has been fully excavated. ${ }^{22}$ There is no evidence that Bath was formally constituted as a chartered town within the Roman administrative system, and nor is there any evidence for a forum

${ }^{21}$ B. W. Cunliffe, 'The Roman tholos from the Sanctuary of Sulis Minerva at Bath, England', in R. I Curtis (ed.), Studia Pompeiana et Classica in Honor of Wilhelmina F. Fashemski. Vol. II. Classica (New Rochelle, NY, 1989), 59.

${ }_{22}$ Cunliffe (n. 20), 151-4. 


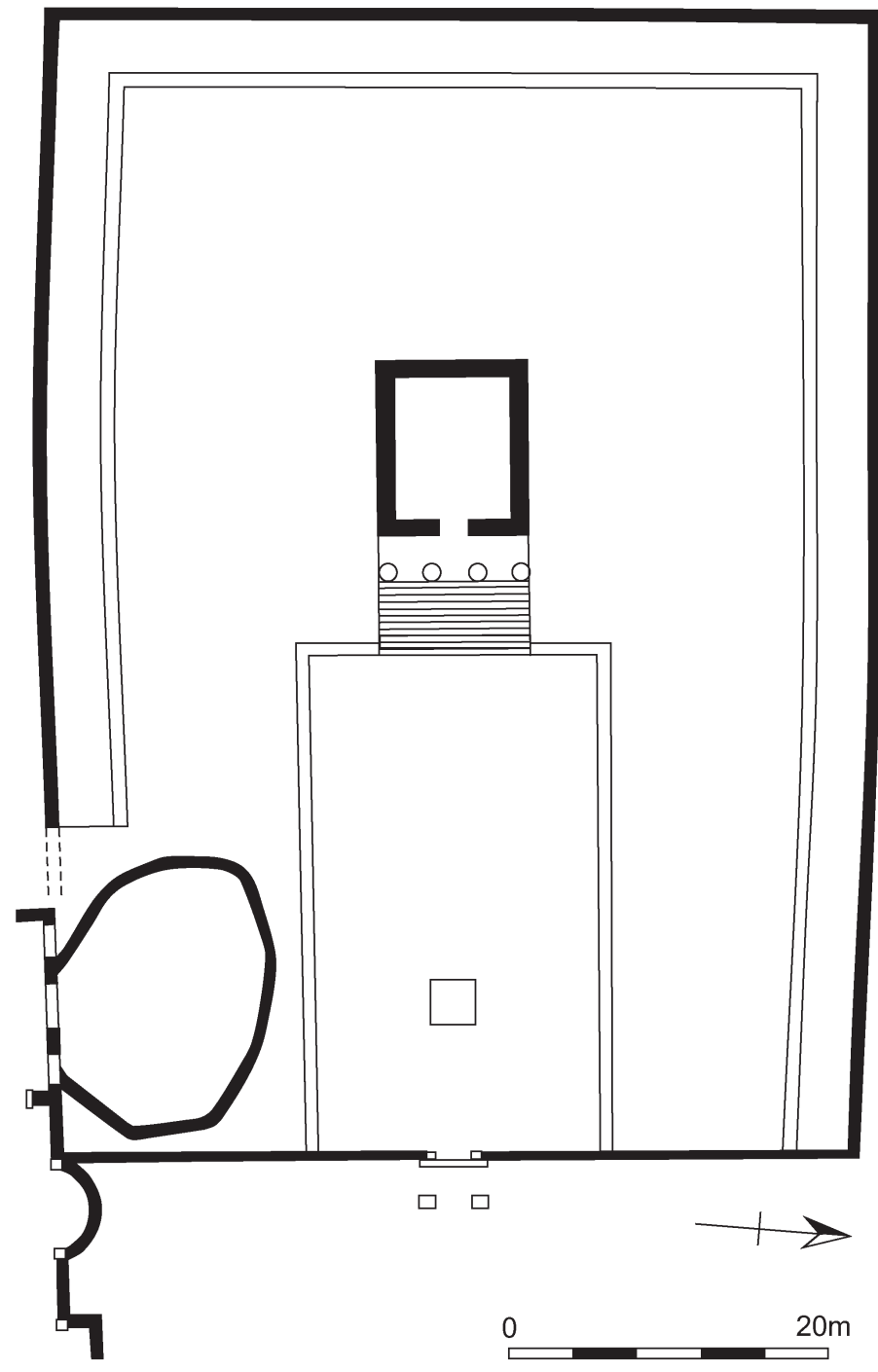

Figure 2. The Roman temple to Sulis Minerva, period 1. After Cunliffe and Davenport (n. 17), figure 110; redrawn by Penny Copeland.

basilica or formal political organizations. It usually falls under the classification of a small town, and is probably best characterized as a sanctuary.

The reconstruction of the rituals of worship at the temple suggest multiple levels of engagement with the divine (figure 2). The area of the precinct was marked off from the street by a stone wall, with 
access via a monumental gateway which extended into the road. ${ }^{23}$ As worshippers entered the complex, they passed into a religious space, the boundary into it clearly marked. At this moment, the view in front of them comprised firstly the monumental altar, and behind it the large podium temple, possibly with the cult statue of the goddess visible through the door of the cella. It was only after entering the precinct that they would have seen the sacred spring and the reservoir, which lay on a second axis comprising the windows of the baths, the spring itself, and the altar. Thus, the monumental altar, measuring $2.2 \mathrm{~m}$ along each side and decorated with images of Olympic deities, formed the pivotal point in the layout of the shrine where the dominant axes intersected. ${ }^{24}$ Later alterations to the area emphasize this importance: an additional platform was built extending the area, and later still a statue base and inscribed base were added.

The emphasis on the area of the altar strongly suggests that sacrifice formed an important part of the ritual surrounding the worship of the goddess. The open area surrounding it points to large public spectacles, possibly preceded by processions through the town to the sacred area of the precinct. As the official and his attendants carried out the ritualized acts of preparing, slaughtering, and butchering the victim, and then burning the appropriate offerings, the community collectively re-established its relationship with the goddess. However, the spatial arrangement of the sacrifice may have changed over time. In the original layout, the collective sacrifice was performed in front of the temple, before the cult statue of the goddess herself, but the construction of the later altar and statue base to the west of the main altar changed the spatial configuration of this relationship. As well as animal sacrifice, libations were probably offered: the group of eight paterae mentioned above, some stamped with the abbreviated name of the goddess, were probably temple plate used for pouring out libations in her honour.

As well as the public offerings of meat and liquids, there is evidence for more private offerings, cast into the spring. Very early on, a wall was built around the spring to create a reservoir, and, at a later date, a series of rectangular and circular bases were sunk into the reservoir, probably for statues and columns. ${ }^{25}$ The majority of the offerings fall into two groups: coins and curse tablets. ${ }^{26}$ From the partial excavation

${ }^{23}$ Cunliffe and Davenport (n. 17).

${ }^{24}$ Ibid., 33-7.

25 Ibid., 42-3.

${ }^{26}$ For a full catalogue of the material recovered from the spring, see Cunliffe (n. 17). 
of the spring, over twelve and a half thousand Roman coins have been retrieved, as well as eighteen Celtic coins that probably also dated to the Roman period. Dropping a coin into a spring or well seems to have been a common religious ritual, paralleled at Coventina's Well on Hadrian's Wall, for example, where over thirteen thousand coins were recovered. ${ }^{27}$ Other items thrown into the spring include jewellery, gemstones, plates, bowls, and military items, as well as wooden and leather objects. Perhaps surprising is the lack of anatomical ex-votos, which might be expected if this was a healing shrine, as often seems to have been the case at thermal springs. ${ }^{28}$ Whilst there are three possible examples, this does not seem to have been a particularly important ritual at the site. In the earliest period, the spring was open, and so offerings could be dropped in either from the precinct, or from the baths through windows overlooking the pool. This tradition continued after the spring was enclosed, which may have made the atmosphere surrounding their dedication more secretive and less public.

A third type of offering can be seen in the dedicatory altars and bases to the gods. There is the temptation with these to isolate the text, extract the name of the deity, and use it as evidence for their worship. However, we need to think about the context of these, and how the act of inscribing formed part of the articulation of the relationship between human and divine. ${ }^{29}$ There are seventeen in total, of which nine are to Sulis Minerva as either single- or double-named. Not all originated from the temple: dedications were also set up to her at the Cross Bath and the Hot Bath sites (RIB 146 and 150 respectively), ${ }^{30}$ reinforcing the idea that the town itself was in some sense sacred to the goddess. However, as is usual in Roman religious space, this did not exclude dedications to secondary deities, such as a dedication to Diana from the Hot Bath (RIB 139). Such inscriptions commemorate publicly an individual act of dedication, providing a permanent marker for a transitory experience. The writing and the subsequent reading of such inscriptions fixed the goddess within the temple, and formed part of a future discourse of appropriate ritual 1985)

27 L. Allason-Jones and B. McKay, Coventina's Well. A Shrine on Hadrian's Wall (Hexham,

${ }^{28}$ F. Yegul, Baths and Bathing in Classical Antiquity (New York, NY, 1992), 124-7.

29 The relationship between writing and ritual is discussed more fully in M. Beard, 'Writing and Religion. Ancient Literacy and the Function of the Written Word in Roman Religion', in J. H. Humphrey (ed.), Literacy in the Roman World (Ann Arbor, MI, 1991), 35.

${ }^{30} \mathrm{RIB}=\mathrm{R}$. G. Collingwood and R. P. Wright, The Roman Inscriptions of Britain. Volume 1. Inscriptions on Stone (Oxford, 1965). 
action. Visitors to the temple, on reading them, would have used them in understanding their own relationship to the goddess: her power and the appropriate rituals to invoke it. Two forms of ritual are recorded: the donation of gifts to the goddess, usually of unknown form, although the statue base dedicated to the Suleviae by the sculptor Sulinus suggests that the gift was the statue itself (RIB 151). The second ritual referred to is that of the vow, the inscription forming the final, but archaeologically most visible, stage in a complex ritual sequence. ${ }^{31}$ This began with the utterance of the vow itself, a deal with the goddess that, if she fulfilled a specific request, the petitioner would undertake some form of act in thanks. An animal sacrifice was the usual thanksgiving offering, recalled in the altar often used for the inscription. ${ }^{32}$ Sometimes the reason for the vow was given: for example, two inscriptions were set up by liberti in thanks for the safety of their former master (RIB 143-4).

A second form of vow is represented through the lead curse tablets, of which 130 have been recovered from the sacred spring, five of which were written in unintelligible squiggles. ${ }^{33}$ These follow a standard pattern of a quasi-legal contract between the deity (not always mentioned) and the petitioner. The similarities between this group in the wording of the curse and the preparation of tablets all point to a formalized ritual process. First, the worshipper wrote out the curse on a lead tablet, copying the correct form supplied by a scribe or specialist temple servant. It has been argued that there were professional scribes who produced these curses, but the corpora at Bath and the nearby shrine at Uley only have two examples between them in the same hand. ${ }^{34}$ In addition, one of the tablets from Bath refers to the copying out of the written page (Tab. Sulis 8: carta picta perscripta). Thus, in order for the curse to be effective, it seems to have been necessary to write out the curse in person, and one possible interpretation of the illegible examples is that they were an attempt by illiterate petitioners to comply with this requirement.

31 T. Derks, 'The Ritual of the Vow in Gallo-Roman Religion', in Metzler, et al. (n. 1), 111; Scheid (n. 9).

32 T. Derks, Gods, Temples and Ritual Practices. The Transformation of Religious Ideas and Values in Roman Gaul, vol. 2, Amsterdam Archaeological Studies (Amsterdam, 1998), 21.

${ }^{33}$ R. S. O. Tomlin, 'The Curse Tablets', in Cunliffe (n. 17), 59. The key synthetic work on curse tablets as a whole is J. G. Gager, Curse Tablets and Binding Spells from the Ancient World (New York, NY, 1992).

${ }^{34}$ R. S. O. Tomlin, 'Writing to the Gods in Britain', in A. E. Cooley (ed.), Becoming Roman, Writing Latin? Literacy and Epigraphy in the Roman West, Journal of Roman Archaeology Supplementary Series 48 (2002), 165. 
The second stage was the concealment of the text. Usually, this was achieved through folding the tablet, hiding the words of the curse, but other strategies might be used: some were written with the letters of the curse reversed, and others in mirror script (reversal of script: Tab. Sulis 44,62; mirror script: 61), and an alternative explanation for the illegible texts is that this was another form of concealment. The final stage was the deposition of the curse within the spring, hiding it completely from the eyes of mortals, and dedicating it to the gods. This reinforced the wording of the curse, which also dedicated the stolen goods to the deity, making the recovery of the stolen goods their concern. There is a strong sense of place within some of the tablets, setting up an association between the fulfilment of the curse, the goddess, and the physical setting of the temple. The writer of one tablet requested that the person who stole his gloves might lose their minds (sic) and eyes in the temple (Tab Sulis 5), whilst whoever stole Civilis' ploughshare was to lose his life within the temple (Tab. Sulis 31 ); others, less vengefully, state merely that the stolen property should be returned to the temple (Tab. Sulis 10, 32, 45). The act of depositing the curse tablet within the spring reinforced the secrecy of the act: the majority of the curses date to the third and fourth centuries $\mathrm{AD}$, and it was at about this time that the spring was enclosed within a separate building, with an entrance from the precinct continuing its link with the temple. Thus, placing the curse within the spring became a more secretive act, removed from public view.

The archaeological evidence from Bath presents a picture of dynamic ritual activity, with different levels of action, from the large-scale public sacrifices to the more private act of dropping a coin into the spring. These multiple levels of engagement warn us against seeing the adoption of Romanized religion as a thin veneer: they suggest a degree of choice and decision-making on behalf of the worshipper in judging what was the most appropriate means of acquiring the good will of the goddess. We can also see the way in which characteristically Roman rituals, such as those of the curse tablets, are adopted and transformed within a local setting. The sheer volume of examples from Bath and the nearby temple of Uley is unparalleled in the Roman empire, and at Bath the custom of depositing them within the spring rather than a grave, for example, shows how the ritual was adapted to the particularities of the local cult. ${ }^{35}$ The cosmopolitan nature of the worshippers, and their official

35 It is possible that the large body of curse tablets from the nearby shrine at Uley were similarly deposited in a pool, pointing to this being a regional practice rather than purely confined to Bath. 
roles within the Roman administrative system, has often been stressed, ${ }^{36}$ but this is drawn from the evidence of the inscriptions on stone, and it should be noted that this only applies to half those named: the other half cannot be characterized. In addition, of the names given on the curse tablets, none are tria nomina names, and over half are 'celtic' in derivation, suggesting that some of the worshippers were more local. This presents the picture of an important sanctuary, used by both the local population and visitors from further afield, all engaged in a series of ritual activities that would not be unfamiliar to someone at the heart of the empire.

\section{The sanctuary town at Munigua}

As I argued earlier, it is conventional to explore ideas of cultural change within a single province but, if we are to examine Roman imperialism at a more global level, we need to think about how the shared social structures operated beyond the level of the individual province. This opens up the question of how far the ritual practices identified at Bath can also be traced in other areas. The Baetican town of Munigua (modern Mulva), like Bath, seems to have drawn its importance from its religious role. It was a pre-Roman settlement, apparently monumentalized in the first half of the first century AD, and granted the status of municipium during the Flavian period. ${ }^{37}$ The prominence of the religious structures, and the apparent downplaying of the forum area suggest that the primary function of the town was religious, in spite of its political constitution. The town was constructed on one side of a hill, dominated by the large sanctuary at the top, the so-called Sanctuario de Terrezas (figure 3). A second temple was positioned on the terrace below, and a third temple lay within the forum precinct, with ramps and stairways joining the various levels. The dedication of the various temples is unclear: inscriptions have been found in the main temple to both Fortuna Crescens Augusta and Hercules Augustus (CILA II 1057, 1060), ${ }^{38}$ and this association of both deities with the emperor, as well as other evidence, has led various commentators to suggest that it was

${ }^{6}$ For example, Millett (n. 2), 110, table 5.2.

37 The site has been excavated by the German Institute since the 1950s; the most complete description of the buildings is T. G. Schattner, Munigua. Cuaranta años de investigaciones (Seville, 2003).

38 CILA = Corpus de Inscripciones Latinas de Andalucía. 


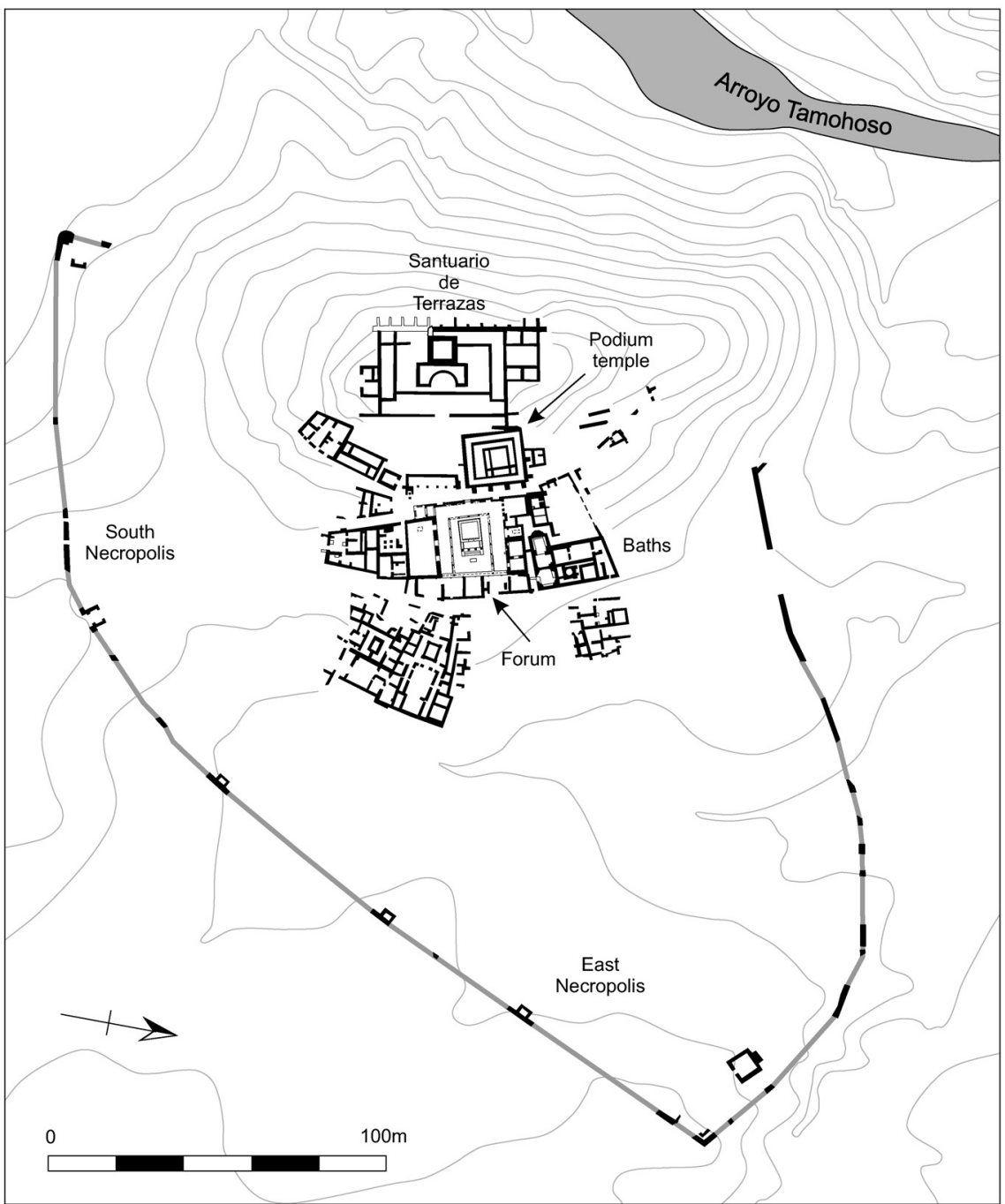

Figure 3. The Roman town of Munigua. After Schattner (n. 37), figure xx; redrawn by Penny Copeland.

dedicated to the imperial cult. ${ }^{39}$ This seems the most plausible dedication for the main temple; however, this assumed dedication is, in part, based upon the supposed ubiquity of the imperial cult in the

39 W. Grünhagen, 'Excavaciones del Sanctuario de Terrezas de Munigua', Congreso Nacional Arqueológica 5 (1959), 275; F. Coarelli, 'Munigua, Praeneste e Tibur. I modelli laziali di un municipio della Baetica', Lucentum 6 (1987), 91; S. J. Keay, 'The Development of Towns in Early Roman Baetica', in S. J. Keay (ed.), The Archaeology of Early Roman Baetica, Journal of Roman Archaeology Supplementary Series 29 (1998), 55. 
Iberian peninsula, but it should be noted that, in reality, there are very few temples to the imperial cult attested on secure evidence, thereby producing an element of circularity in the argument. ${ }^{40}$ We have even less evidence for the deities worshipped in the other two temples: there is a shrine to Dis Pater in the forum, but it is unclear whether this reflected the dedication of the temple itself.

The Sanctuario de Terrezas was clearly the dominant temple within the town. It was laid out over three terraces; on the top terrace was the cella itself, raised on a tall podium. ${ }^{41}$ Below this was a semicircular exedra, with courtyards on either side surrounded by a series of rooms, and on the lowest level, a long, open space accessed from the town via ramps at either end. The cella lay at the pivotal position architecturally, with the series of symmetrical ramps and stairways uniting at its entrance. The worshipper approached the shrine along a ceremonial route leading from the south gate of the town. This led through the heart of the lower town, past the forum and a two-storey portico, past the podium temple, and up a ramp to the lower terrace. This was mirrored by a second route, and although this was steeper and less accessible, it was formalized with a monumental structure to deal with both the turn and the slope. ${ }^{42}$ These processional routes led into the lower terrace of the shrine through some form of gateway, indicating a separation of ritual space from the rest of the town. ${ }^{43}$ This suggests that formal processions were an important element of specific festivals, and part of a local religious calendar. They may have included cult images of the deity, and possibly sacrificial victims, and the participants may have been grouped in a specific order, reflecting local hierarchies and positions of religious authority. ${ }^{44}$ This would have established a sacred route through the town, recalled in the minds of worshippers when they approached the temple on other occasions.

Reconstructing the public rituals enacted in front of these temples is problematic, and challenges the picture of a normative set of rituals. Sacrifice is usually seen as the primary rite at most sites, but, here, there is surprisingly little evidence for its prominence. None of the

40 This approach is critiqued in G. Alföldy, 'Subject and Ruler. Subjects and Methods. An Attempt at a Conclusion', in A. Small (ed.), Subject and Ruler. The Cult of the Ruling Power in Classical Antiquity, Journal of Roman Archaeology Supplementary Series 17 (1996), 237.

${ }^{41}$ Grünhagen, (n. 39); Schattner (n. 37).

${ }^{42}$ Schattner (n. 37), 39-42, 47.

43 Ibid., 30.

${ }^{44}$ I. S. Ryberg, Rites of the State Religion in Roman Art, Memoirs of the American Academy at Rome vol. 22 (1955), 42-4, 75-7. 
three temples have evidence for a permanent altar in front of the cella, and there is only one example of a dedicatory altar from the town. Taken together, this does not rule out the possibility of sacrifice as part of the ritual experience of the townspeople, but it does raise the question of how it was incorporated into the sacred space of the shrine: here it lacks the permanent architectural expression which we see at other sites. Instead, the best evidence we have for sacrifice relates to the final stage: the consumption of the meat in a communal banquet. Two inscriptions record the provision of a banquet to participants of both sexes (CILA II 1055, 1058), demonstrating that such communal feasts were an important part of religious life. If the meat was from sacrificial victims, and, admittedly, it is uncertain whether this was the case, then, unusually, the act of consumption is being commemorated, rather than the more usual sacrifice itself.

This still leaves the question of the nature of public rituals within the town. In the Sanctuario de Terrezas, the exedra, side courtyards, and lower terrace all provide a venue for large-scale rituals of some kind, but the podium temple and the forum temple are quite different. The former was enclosed within a precinct wall, which left very little space for a congregation in front of the temple..$^{45}$ The forum temple almost completely fills the courtyard, again leaving little space for large public ceremonies. It was quite difficult to approach from the street, requiring the worshipper to enter through one of the two narrow doors and go around the temple through the portico. They were both of lesser importance than the main Sanctuary, being decorated with painted stucco rather than the elaborate multicoloured marble which adorned the latter. Both temples were highly visible to anyone approaching, and reinforced the way in which the religious buildings visually dominated the town, but it is very difficult to envisage them being used within a calendar of large-scale public rituals. Instead, the ritual activity of the town seems to have been dominated by the more private act of dedication, with the majority of inscriptions recording the donation of an offering of some kind. One of the most generous was the dedication of a bronze statue of a horse set upon an inscribed granite pedestal and dedicated to Dis Pater (CILA II 1056). The statue was placed in an open-fronted room within the forum, presumably the stable whose donation was recorded in the same inscription. The forum was also the site for a statue

45 Schattner, (n. 37); T. Hauschild, 'Los templos romanos de Munigua (Sevilla)', in AA. VV. (ed.), Templos Romanos de Hispania, Cuadernos de Arquitectura Romana vol. 1 (Murcia, 1991), 133. 
dedicated to Bonus Eventus Augustus in thanks for the donor's election as a priest (CILA II 1054). Others made dedications in memory of deceased individuals (CILA II 1055, 1057), or gave no explicit reason. In contrast to the inscriptions at Bath, here there is only a single example recording a vow, and this is on the only dedicatory altar from the site (CILA II 1063). ${ }^{46}$ It was set within a small shrine on the processional route, opposite the entrance to the forum, and celebrates the fulfilment of a vow, although, as the inscription has been damaged, the reason for it is unknown.

Compared to Bath, Munigua presents a very different picture of ritual worship. Here, there were a number of religious spaces, with the Sanctuario de Terrezas as the most prominent. The layout of the town suggests that the visibility of these temples was an important factor, possibly more important than their accessibility. The formalized approach to the main sanctuary suggests that processions were part of a ritual calendar, but whether they then led to a formal sacrifice is problematic. The inscriptions demonstrate that formal donation was a key ritual, but that vows were more infrequent. We cannot say conclusively from the epigraphic record that sacrifices and vows were completely absent, only that they were not formally memorialized, suggesting that they were considered less important. Furthermore, this lack of a permanent marker means that they were not recalled by later visitors to the temples, and so did not form part of their recognition of how to act within this particular setting.

\section{Reconstructing Roman ritual}

Through a detailed examination of archaeological evidence, we can reconstruct some of the rituals used to invoke and placate the power of the gods. The picture presented is that of a dynamic ritual life, with each site having a distinctive local character. It is easy to downplay the importance of these repeated acts, but the knowledge of how to act within a religious setting was part of people's knowledge of the divine beings. When we think about the cultural homogeneity (or differences) within the Roman empire, we usually concentrate on deities, temples, and iconography, but part of that homogeneity was also a shared repertoire of ritual practices. This ties in with new ways of thinking about cultural identity in the provinces. Roman

46 Schattner (n. 37), 42-5. 
archaeologists are increasingly arguing that Romanization and a Roman identity was more than the acquisition of Roman material culture: the buildings, pottery, coinage, dress which characterize the archaeological record were in reality bound up in new ways of being, through which the people of the provinces understood their own identity and their place within the world. ${ }^{47}$ Part of this discourse of Roman identity was religion, and through these continually performed acts of worship, they entered into a shared experience of interaction with the divine. Thus, this ideology of religion became one of the shared social structures that held the empire together, and formed a part of the cultural changes evident within the archaeological record. Furthermore, this idea of the wider social structures being enacted and replicated at a local level allows us to think about the Roman empire on a large scale, and to explore the workings of imperialism and its power structures.

However, this shared experience should not be confused with a homogenous experience, as the two case studies demonstrate. There are some similarities between the sites, but these co-exist with very localized characteristics. Certain features are apparent in both: dedications, processions, specialised ritual space, inscriptions, and possibly sacrifices. Nevertheless, this does not constitute a blueprint for 'correct worship', and there are clear variations: the importance of the curse tablets and vows at Bath, the emphasis on donations and the visibility of the temples at Munigua. Both lack the association with religious games $(l u d i)$, which we see at other sites. There is no simple explanation for these differences: neither site has concrete evidence for a pre-conquest ritual use, and so it is difficult to argue for some form of continuity. Furthermore, this localized interpretation of Roman culture can be traced in other social experiences, such as urbanism or the image of the power of the emperor. ${ }^{48}$ Instead, we should view this as part of what Greg Woolf has termed 'joining the insiders' debates about what that package [of Roman culture] did or ought to consist of' ${ }^{49}$ These debates were conducted in writing, and we can trace them in the texts that have come down to us. But they

47 Woolf (n. 2); J. D. Hill, 'Romanisation, Gender and Class. Recent Approaches to Identity in Britain and their Possible Consequences, in S. James and M. Millett (ed.), Britons and Romans. Advancing an Archaeological Agenda', Council for British Archaeology Research Report 125 (2001), 12; Gardner (n. 2).

48 This argument is advanced in more detail in L. Revell, Roman Imperialism and Local Identities (Cambridge, in preparation).

49 Woolf (n. 2), 11; a similar argument is made in J. C. Barrett, 'Theorising Roman Archaeology', in K. Meadows, et al. (n. 12), 1. 
were also conducted through ways of living, and this is represented within the variability of the archaeological record. This undermines the usual methodology of building up a normative picture on a large scale. To understand how religion formed part of the way in which a Roman identity was internalized and maintained, we need to acknowledge the dynamic and variable nature of Roman ritual within the local context. However, it also has the power of allowing us to reconstruct the social structures or ideologies that provided coherence to the shared culture of the Roman empire, and ultimately to integrate the local nature of the archaeological record with the global scale of the empire itself. 